\title{
BODY-SIZE INFLUENCE ON DEFENSIVE BEHAVIOR OF AMAZONIAN MOTHS: AN ECOPHYSIOLOGICAL APPROACH
}

\author{
OLIVEIRA, F. B. \\ Departamento de Fisiologia, Instituto de Biociências, Universidade de São Paulo, Rua do Matão, \\ tr. 14, n. 321, Cidade Universitária, CEP 05508-900, São Paulo, Brazil \\ Correspondence to: Felipe Bandoni de Oliveira, Departamento de Fisiologia, \\ Instituto de Biociências, Universidade de São Paulo, Rua do Matão, tr. 14, n. 321, \\ Cidade Universitária, CEP 05508-900, São Paulo, Brazil, e-mail: fbo@ib.usp.br
}

Received September 4, 2002 - Accepted September 22, 2003 - Distributed February 28, 2005

(With 1 figure)

\begin{abstract}
Ectotherm locomotion is restricted by low temperatures, and many species, such as some flying insects, need to achieve thermal thresholds before taking off. Body size influences heat exchange between an animal and the environment. Therefore, larger animals have higher thermal inertia, and necessarily spend more time in pre-flight warming up, a critical period when they remain exposed and more susceptible to predators. Thus, one could expect larger animals, along their evolutionary history, to have developed a more diversified repertoire of defensive behaviors when compared to their smaller counterparts. Moths are an interesting model for testing this hypothesis, as they exhibit considerable variation in body size and many species present pre-flight warming up by muscle shivering, an evidence of thermal restriction on locomotion. I registered the responses of 76 moths immediately after simulating the attack of a predator and then associated behavioral response to body size. I conducted the experiments at 20 and $25^{\circ} \mathrm{C}$ to check for possible thermal restrictions on behavior, and identified animals to the family level to check for the effects of a common phylogenetic history. When disturbed at $25^{\circ} \mathrm{C}$, smaller moths tend to fly, while larger ones tend to run. At $20^{\circ} \mathrm{C}$ almost all moths ran, including the smaller ones, indicating a possible thermal restriction on flight. Corroborating the proposed hypothesis, a more diversified repertoire of defensive behaviors was registered among larger moths. An alternative interpretation would be that common behaviors among related moths could be explained by common phylogenetic histories. However, two facts support the physiological restriction hypothesis: (1) the analysis within Sphingidae and Geometridae (not closely related families) showed similar results to those of the overall analysis, and (2) a more diverse repertoire of defensive behaviors was associated to the lower, and therefore more restrictive to locomotion, temperature $\left(20^{\circ} \mathrm{C}\right)$.
\end{abstract}

Key words: body size, thermoregulation, defensive behavior, temperature, moths.

\section{RESUMO}

\section{Influência do tamanho corpóreo sobre o comportamento defensivo de mariposas amazônicas: uma abordagem ecofisiológica}

A locomoção de animais ectotérmicos é restringida por temperaturas baixas, e muitas espécies, como alguns insetos, precisam atingir certas temperaturas antes de voar. O tamanho corpóreo influencia as trocas de calor entre um organismo e o ambiente, dessa forma, animais maiores, por apresentarem maior inércia térmica, passam mais tempo aquecendo-se antes do vôo, período em que ficam mais expostos à predação. Assim, seria esperado que, ao longo de sua história evolutiva, animais maiores desenvolvessem repertório de comportamentos defensivos mais diversificado que os menores. As mariposas são um grupo interessante para testar essa hipótese por apresentarem grande variação de tamanho e aquecerem-se com tremor muscular antes do vôo, uma evidência da restrição térmica à locomoção. Registrei o comportamento 
de 76 mariposas imediatamente após uma simulação de ataque de um predador, associando a resposta observada ao tamanho corpóreo. Conduzi os experimentos a 20 e $25^{\circ} \mathrm{C}$ para averiguar eventuais restrições térmicas sobre o comportamento defensivo e identifiquei os animais até o nível de família para verificar os efeitos de história filogenética comum. Quando perturbadas a $25^{\circ} \mathrm{C}$, mariposas menores tenderam a voar, enquanto as maiores correram. A $20^{\circ} \mathrm{C}$, quase todos os animais correram, incluindo os menores, evidenciando possível restrição térmica ao vôo. As mariposas maiores apresentam repertório de comportamentos defensivos mais diversificado, corroborando a hipótese proposta. Uma interpretação alternativa seria a de que respostas comportamentais similares poderiam ser explicadas por uma história filogenética comum. Entretanto, duas evidências apóiam a hipótese de restrições fisiológicas à locomoção: (1) a análise com Sphinghidae e Geometridae (famílias distantes filogeneticamente) apresentou o mesmo resultado que a análise geral e (2) foi detectada associação entre maior repertório de comportamentos defensivos e temperatura experimental mais baixa e, portanto, mais restritiva à locomoção.

Palavras-chave: tamanho corpóreo, termorregulação, comportamento defensivo, temperatura, mariposas.

\section{INTRODUCTION}

Temperature may affect many aspects of an animal's life, from its daily activity rhythm to its geographic distribution (Hutchinson \& Dupré, 1992; Heinrich, 1996). The environmental temperature influence is even stronger on ectotherms, since they use external heat sources to regulate body temperature (Hochachka, 1991). According to body size, there is considerable variation in temperature influence: small animals that have larger areas in contact with the environment in relation to body volume warm up and cool off more rapidly than larger animals (Schmidt-Nielsen, 1984).

In some species of bees, moths, beetles, and dragonflies, locomotion is strongly related to temperature (Heinrich, 1972; Heinrich \& Bartholomew, 1971; Heinrich \& McClain, 1986; May, 1995). To take off, larger insects have to attain body temperatures many degrees higher than that of the environment, which may be done by thoracic muscle contractions in a process similar to shivering in endotherms (Boettiger, 1960; Heinrich \& Bartholomew, 1971; Coombs, 1993). Thus, because they need more heat to warm up than do smaller ones, larger animals spend more time exposed while thermoregulating, and thus have higher probabilities of being attacked when still cool and not ready to fly (De Marco, 1998). Therefore, one might imagine that along their evolutionary course, the larger insect species could have developed a greater diversity of defensive behaviors, since their flight is frequently physiologically constrained.

Moths are good models on which to test this hypothesis, because their body sizes vary greatly among species, and many of them exhibit pre-flight warm up, evidencing thermal restriction on locomotion. Besides, moths exhibit a great variety of defensive behaviors (Edmunds, 1974), as well as great diversity in tropical rainforests (Barlow \& Woiwod, 1989). In this study, I tested the response of several Amazonian moths to a simulated predator attack. The results are discussed from an ecophysiological perspective.

\section{MATERIAL AND METHODS}

Moths were collected on August 27-30, 2001, in the Reserva do $\mathrm{km} 41$ (INPA/PDBFF), $70 \mathrm{~km}$ north of Manaus, northern Brazil (2 24 '26' 'S; $\left.59^{\circ} 43^{\prime} 44^{\prime \prime} \mathrm{W}\right)$. Independent of taxonomic group, the moths were collected between 19 and $23 \mathrm{~h}$ with light traps. They were held in humidified recipients until the following day. Thirty minutes prior to the beginning of the experiments, the temperature was kept at that at which the test would be performed. All these experiments were conducted between 9 and $11 \mathrm{~h}$, and to test whether possible differences found in defensive behavior were related to temperature, I randomly assigned each individual to testing at either 20 or $25^{\circ} \mathrm{C}\left( \pm 1^{\circ} \mathrm{C}\right)$.

I released each moth on the ground of a $1.8 \mathrm{x}$ $1.2 \times 1.0 \mathrm{~m}$ area. To simulate the attack of a predator, I gently pressed the distal region of its hind wings with a forceps, and registered the immediate reaction, classifying it in one of the following behavioral categories: flying, jumping, running, wing beating, or freezing. After the behavioral tests, I identified the moths to the family level and measured each animal's length (from the frons to the tip of the abdomen) and 
largest thoracic width. Assuming that a moth's body shape is roughly cylindrical, I estimated the volume using the formula:

$$
\mathbf{V}=\pi(a / 2)^{2} \times b
$$

where $a$ is width and $b$ is body length.

In order to minimize phylogenetic effects on the behaviors studied, I analyzed separately the families Sphingidae and Geometridae, which are the two groups with higher body size variation. To test whether the behavioral responses of the moths were related to body size, I used logistic regressions, a procedure that quantifies the association between a binary-expressed dependent variable and a continuous independent variable (Motulsky, 1995). All analyses were performed in SYSTAT 8.0 (Wilkinson, 1988).

\section{RESULTS}

Body length of the captured moths varied from 4.2 to $64.0 \mathrm{~mm}($ median $=13.3 \mathrm{~mm})$ and body volume varied from 1 to $11000 \mathrm{~mm}^{3}$ (median $=72.7$ $\mathrm{mm}^{3}$ ). However, most of the moths were relatively small: $65 \%$ were $18 \mathrm{~mm}$ or smaller. Noctuidae,
Pyralidae, Geometridae, and Sphingidae were the best represented families among the identified moths, and other families and non-identified individuals totaled 21 animals (Table 1).

More behavioral categories were observed among larger moths at both experimental temperatures. All behavioral categories were registered at both temperatures, except for freezing, observed only at $20^{\circ} \mathrm{C}$ (Tables 2 and 3 ). At $25^{\circ} \mathrm{C}$, most moths flew, and a negative relationship between body volume and flight response was detected $(\mathrm{G}=6.918$; $\mathrm{p}=0.009 ; \mathrm{n}=43$ ), as well as a positive relationship between body volume and running response $(\mathrm{G}=$ 15.389; $\mathrm{p}<0.001 ; \mathrm{n}=43$; Fig. 1), indicating that at $25^{\circ} \mathrm{C}$ smaller animals tended to fly and larger animals tended to run.

At $20^{\circ} \mathrm{C}$, however, flight probability and size were not related $(\mathrm{G}=0.895 ; \mathrm{p}=0.344 ; \mathrm{n}=33$; Fig. 1$)$ and there was a negative relationship between running and size $(\mathrm{G}=9.820 ; \mathrm{p}=0.002 ; \mathrm{n}=33$; Fig. 1$)$. In other words, at $20^{\circ} \mathrm{C}$ smaller moths had higher probabilities of running than their larger counterparts. None of the other defensive behaviors observed (jumping, wing beating, or freezing) was significantly related to body size.

TABLE 1

Number of captured animals per family, with respective body size range. Medians are between parentheses.

\begin{tabular}{|l|c|c|c|}
\hline \multicolumn{1}{|c|}{ Family } & n & Length $(\mathbf{m m})$ & Volume $\left.\mathbf{( m m}^{\mathbf{3}}\right)$ \\
\hline Noctuidae & 32 & $10.4-20.3(16.9)$ & $51.0-322.7(157.4)$ \\
\hline Pyralidae & 8 & $4.4-8.8(6.4)$ & $1.3-36.5(7.6)$ \\
\hline Geometridae & 8 & $5.1-13.8(7.4)$ & $1.0-73.2(10.7)$ \\
\hline Sphingidae & 8 & $39.5-63.9(49.2)$ & $1230.7-11400.3(3734.9)$ \\
\hline Other families and non-identified & 20 & $4.2-35.4(10.4)$ & $1.6-2103.3(34.5)$ \\
\hline
\end{tabular}

TABLE 2

Frequency of moth behavioral responses at 20 and $25^{\circ} \mathrm{C}$ when gently pressed with forceps on the hind wings.

\begin{tabular}{|l|c|c|}
\hline \multicolumn{1}{|c|}{ Response } & $\mathbf{2 0}^{\circ} \mathbf{C}$ & $\mathbf{2 5}^{\circ} \mathbf{C}$ \\
\hline Flies & 11 & 33 \\
\hline Jumps & 14 & 6 \\
\hline Runs & 3 & 3 \\
\hline Beats wing & 2 & 1 \\
\hline Freezes & 3 & 0 \\
\hline Total & 33 & 43 \\
\hline
\end{tabular}




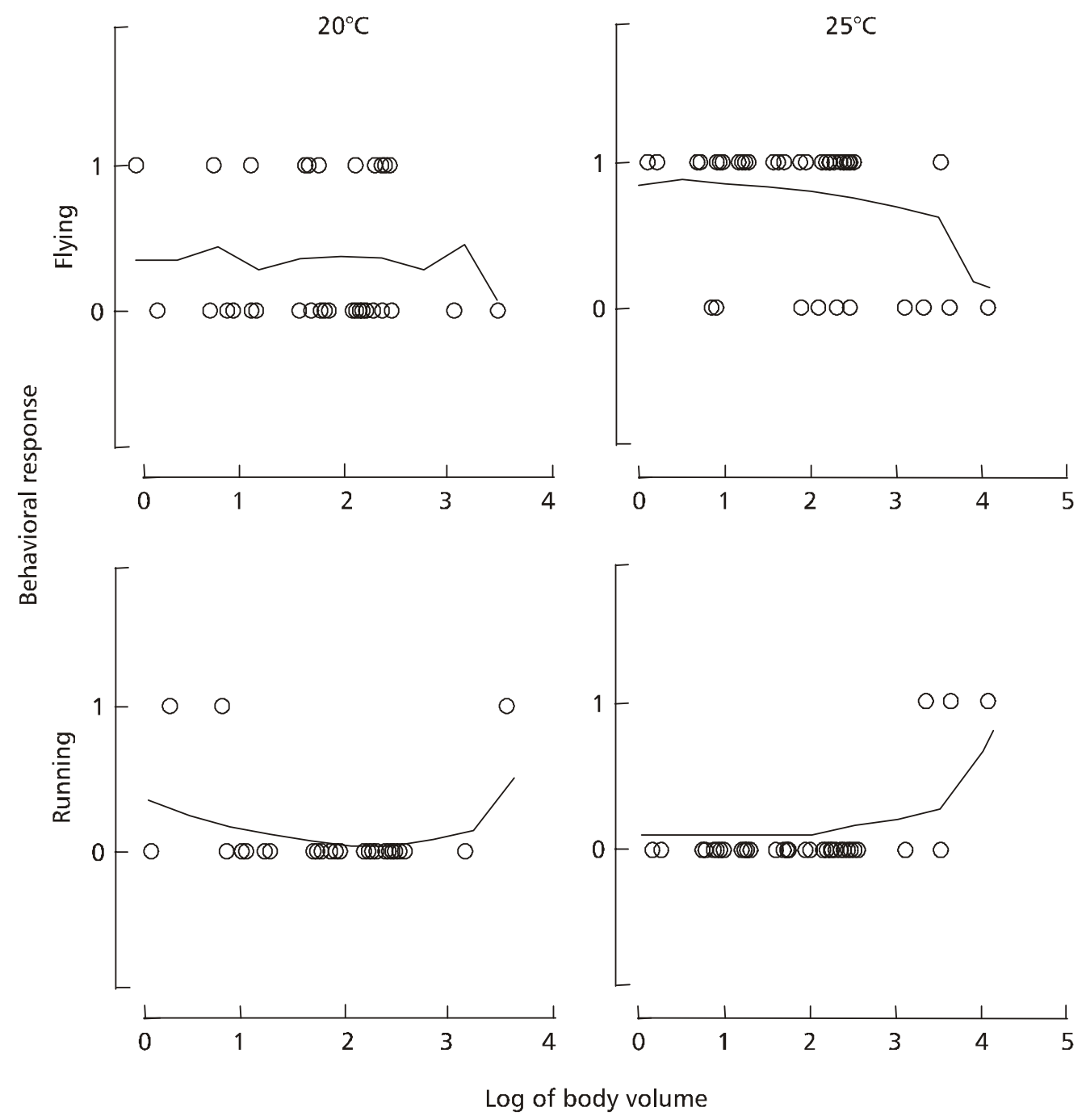

Fig. 1 - Relationship between the logarithm of body volume and observed response of a moth when stimulated at 20 and $25^{\circ} \mathrm{C}$ : $0=$ absence of behavior, $1=$ occurrence of behavior.

TABLE 3

Defensive behaviors observed at 20 and $25^{\circ} \mathrm{C}$ in different body size classes: $\mathrm{fl}=$ flying; $r=$ running; $j=$ jumping; $w=$ beating wing; $f r=$ freezing.

\begin{tabular}{|l|c|c|}
\hline \multicolumn{1}{|c|}{ Volume $\mathbf{( m m}^{\mathbf{3}} \mathbf{)}$} & $\mathbf{2 0}^{\circ} \mathbf{C}$ & $\mathbf{2 5}^{\circ} \mathbf{C}$ \\
\hline $1-10$ & $\mathrm{fl}, \mathrm{j}, \mathrm{r}$ & $\mathrm{fl}, \mathrm{j}$ \\
\hline $10-100$ & $\mathrm{fl}, \mathrm{j}$ & $\mathrm{fl}, \mathrm{j}$ \\
\hline $100-1000$ & $\mathrm{fl}, \mathrm{j}, \mathrm{b}, \mathrm{fr}$ & $\mathrm{fl}, \mathrm{j}, \mathrm{b}$ \\
\hline $1000-11400$ & $\mathrm{r}, \mathrm{fr}$ & $\mathrm{fl}, \mathrm{j}, \mathrm{r}$ \\
\hline
\end{tabular}


The results within Sphingidae and Geometridae families revealed tendencies similar to those detected by the overall analysis. At $20^{\circ} \mathrm{C}$, among sphingids, the two larger moths froze, while two smaller ones ran; at $25^{\circ} \mathrm{C}$ the two larger ones ran or jumped, while the smaller ones flew. Within Geometridae, at $20^{\circ} \mathrm{C}$ the two larger moths jumped and the two smaller ones flew, whereas at $25^{\circ} \mathrm{C}$ all the moths flew.

\section{DISCUSSION}

The hypothesis that larger moths have developed a more diverse repertoire of defensive behaviors because of thermal constraints on locomotion was corroborated by the results of this study. Overall, more behavioral categories were registered at the lower experiment temperature among larger animals. Smaller body size and the higher temperature used seemed to be more conducive to locomotion, as evidenced by the fact that under these conditions, most animals flew.

Different defensive behaviors demand different energy levels, and probably sustained flight is the most expensive (Ellington et al., 1990). This hypothesis explains why at $20^{\circ} \mathrm{C}$, a relatively more restrictive condition, a higher frequency of presumably "low energy" behaviors, e.g., freezing, was observed when compared to the $25^{\circ} \mathrm{C}$ tests, while at the higher temperature, more than $75 \%$ of the animals flew (Table 1) (a presumably high-energy behavior). If the same tests were to be conducted at temperatures higher than $25^{\circ} \mathrm{C}$, even more animals could be expected to fly (Coombs, 1993; May, 1995). Strong muscle performance, which is necessary for flight, is based ultimately on temperature-dependent physiological and biochemical processes (Boettiger, 1960; Coombs, 1993). That would explain why animals are able to fly only in conditions adequate for maintaining high body-temperatures, i.e., high environmental temperatures combined with small body-size, as showed by the negative relationship observed between body size and flight probability at $25^{\circ} \mathrm{C}$ (Fig. 1). The same relationship would be expected at $20^{\circ} \mathrm{C}$, but this temperature seemed to be critical for a few small animals that did not fly. These animals probably have large body volumes in relation to wingspan and, therefore, may be relatively heavier, or have an unfavorable area/volume relationship for reaching body temperatures high enough to fly.

Running may be the second most energetic behavior observed in this study. While at $25^{\circ} \mathrm{C}$ only larger moths ran, at $20^{\circ} \mathrm{C}$ some of the smaller animals also ran, another indication that thermal and body size constraints affect flying behavior (Fig. 1). Other factors, however, could help to explain these results. The first one is interindividual differences in thermal tolerance relative to locomotion: as the environmental temperature when animals were captured was close to $25^{\circ} \mathrm{C}$, for some individuals the critical temperature might have been $20^{\circ} \mathrm{C}$. Secondly, movements in captivity were not controlled and it is possible that some moths struggled inside the recipients, consequently reducing energy stores available for flying when submitted to testing. Finally, most moths are known to have body hair that may affect heat exchange with the environment and, therefore, work as insulators (Church, 1960; Casey \& Joos, 1983); variation in insulation may determine flying capacity under certain conditions, such as temperature in the $20^{\circ} \mathrm{C}$ tests.

Although different defensive behaviors probably result in different levels of energy depletion (Ellington et al., 1990), it is difficult to make inferences about their effect under natural conditions, because this depends on the kind of predator involved. If the predator can detects movement, like praying mantises or frogs, perhaps the best strategy is to freeze. But if it is an animal, like a small mammal, with a developed olfactory sense, maybe the best strategy is to jump or fly away. Thus, there is not necessarily a relationship between effectiveness of predatoravoiding behavior and the energy it requires.

All the patterns observed could be the outcome of a phylogenetic effect instead of being explained as physiological constraints on exercise. In other words, it is possible that individuals from closely related species show similar behavior not because of similar physiological and environmental conditions, but because they share a common evolutionary history (Harvey \& Pagel, 1991). One way of testing this hypothesis is to study tendencies in unrelated groups (e.g., species within different families); if the same tendency is found among distinct groups, it is probably not a phylogenetic feature, but rather an ecological or physiological phenomenon (Navas, 1996). This analysis of the behavioral responses within the Sphingidae and Geometridae families suggested that larger animals are more constrained with respect to flying. Although this conclusion is based on a small number of tests, the data, together with the higher variation in defensive behavior among larger moths within these two families, corroborate the physiological restriction hypothesis. 
Finally, I should mention that the statement that larger animals are more susceptible to predation due to locomotion constraints has its limits. This study did not assess camouflage, wing-color patterns, and other primary defenses that also play a role in predator avoidance (Edmunds, 1974; Brunetti et al., 2001). Furthermore, one of the hypotheses for explaining gigantism in some animals, including insects, proposes a reduction in potential predators (Palmer, 2002). Thus, the best explanation is that each species represents an evolutionary balance between its physiological constraints and ecological pressures.

Acknowledgements - Many thanks to all colleagues in the field course Ecologia da Floresta Amazônica 2001, who helped in this project from its conception through ensuing discussions. Eduardo Venticinque, Glauco Machado, Jansen Zuanon, José Eduardo de Carvalho, Rodrigo H. Willemart, and an anonymous reviewer made valuable suggestions that greatly improved the manuscript. Financial support from the Instituto Nacional de Pesquisas da Amazônia (INPA) and the Smithsonian Institution made this work possible.

\section{REFERENCES}

BARLOW, H. S. \& WOIWOD, I. P., 1989, Moth diversity of a tropical forest in peninsular Malaysia. J. Trop. Ecol., 5: $37-50$.

BOETTIGER, E. G., 1960, Insect flight muscles and their basic physiology. Annu. Rev. Entomol., 5: 1-15.

BRUNETTI, C. R., SELEGUE, J. E., MONTEIRO, A., FRENCH, V., BRAKEFIELD, P. M. \& CARROLL, S. B., 2001, The generation and diversification of butterfly eyespot color patterns. Curr. Biol., 11: 1578-1585.

CASEY, T. M. \& JOOS, B. A., 1983, Morphometrics, conductance, thoracic temperature, and flight energetics of noctuid and geometrid moths. Physiol. Zool., 56: 160173.

COOMBS, M., 1993, Endothermy and flight thresholds for Helicoverpa punctigera and Helicoverpa armigera (Lepidoptera, Noctuidae). Austr. J. Zool., 41: 577-587.

CHURCH, N. S., 1960, Heat loss and body temperature of flying insects. II. Heat conduction within the body and its loss by radiation and convection. J. Exp. Biol., 37: 186-212.

DE MARCO, P. J., 1998, The amazonian campina dragonfly assemblage: patterns in microhabitat use and behavior in a foraging habitat (Anisoptera). Odonatologica, 27: 239248 .
EDMUNDS, M., 1974, Defense in animals: a survey of antipredator defenses. Longman, New York, USA, 357p.

ELLINGTON, C. P., MACHIN, K. E. \& CASEY, T. M., 1990, Oxygen consumption in bumblebees in forward flight. Nature, 347: 472-473.

HARVEY, P. H. \& PAGEL, M. D., 1991, The comparative method in evolutionary biology. Oxford University Press, Oxford, UK, 239p.

HEINRICH, B., 1972, Temperature regulation in the bumblebee, Bombus vagans: a field study. Science, 175: 185-187.

HEINRICH, B., 1996, The thermal warriors: strategies of insect survival. Harvard University Press, Cambridge, Massachusetts, USA, and London, UK, 221p.

HEINRICH, B. \& BARTHOLOMEW, G. A., 1971, An analysis of pre-flight warm-up in the sphinx moth, Manduca sexta. J. Exp. Biol., 55: 223-239.

HEINRICH, B. \& MCCLAIN, E., 1986, "Laziness" and hypothermia as a foraging strategy in flower scarabs (Coleoptera: Scarabaeidae). Physiol. Zool., 59: 273-282.

HOCHACHKA, P. W., 1991, Temperature: the ectothermy option. pp. 313-322. In: P. W. Hochachka \& T. P. Mommsen (eds.), Biochemistry and molecular ecology of fishes, vol. I. Elsevier Science Publishers, Amsterdam, The Netherlands, 350p.

HUTCHINSON, V. H. \& DUPRÉ, R. K., 1992, Thermoregulation. pp. 206-249. In: M. E. Feder \& W. W. Burggren (eds.), Environmental physiology of the amphibians. The University of Chicago Press, Chicago, USA, 645p.

MAY, M. L., 1995, Dependence of flight behavior and heatproduction on air-temperature in the green darner dragonfly Anax junius (Odonata, Aeshnidae). J. Exp. Biol., 198: 23852392.

MOTULSKY, H., 1995, Intuitive Biostatistics. Oxford University Press, Oxford, UK, 386p.

NAVAS, C. A., 1996, The effect of temperature on the vocal activity of tropical anurans: a comparison of high and lowelevation species. J. Herp., 30: 488-497.

PALMER, M., 2002, Testing the 'island rule' for a tenebrionid beetle (Coleoptera, Tenebrionidae). Acta Oecologica, 23: 103-107.

SCHMIDT-NIELSEN, K., 1984, Scaling: why is animal size so important? Cambridge University Press, Cambridge, UK, $241 \mathrm{p}$.

WILKINSON, L., 1988, SYSTAT: the System for Statistics. SYSTAT Inc., Evanston, USA. 